\title{
Health Status of Broiler Chickens Fed Diets with Equi-Protein Replacement of Soybean Meal with Groundunt Cake
}

\author{
Faluyi Oyetayo Bolanle $1, \mathrm{a},{ }^{,}$, Onile Tosin Olayemi ${ }^{1, \mathrm{~b}}$,

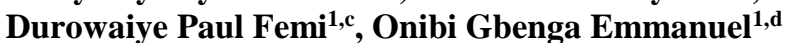

${ }^{1}$ Department of Animal Production and Health, Federal University of Technology, Akure, Nigeria *Corresponding author

\begin{tabular}{|c|c|}
\hline R T I C L E I N F O & B S T R A C T \\
\hline $\begin{array}{l}\text { Keywords: } \\
\text { Alternative feed ingredients } \\
\text { Animal protein } \\
\text { Broiler chickens } \\
\text { Immunity } \\
\text { Newcastle }\end{array}$ & $\begin{array}{l}\text { This study was carried out to investigate the effect of equi-protein replacement of soybean meal } \\
\text { with groundnut cake on immune status, haematology and serum biochemical parameters of broiler } \\
\text { chickens. A total of One hundred and twenty (120) Cobb's day old chicks were randomly allocated } \\
\text { to five (5) dietary treatments of three (3) replicates and eight ( } 8 \text { ) chicks per replicate in a completely } \\
\text { randomized design. The Diet I was the control diet with } 100 \% \text { SBM as the major plant protein } \\
\text { source while in other diets, SBM was replaced with } 25,50,75 \text { and } 100 \% \text { GNC in equi-protein basis } \\
\text { and designated as Diets II, III, IV and V respectively. Feed and water were provided ad-libitum } \\
\text { throughout the experimental period of } 56 \text { days. Newcastle disease (ND) vaccines were administered } \\
\text { following a stipulated regime. At the end of the experiment two birds were randomly selected from } \\
\text { each replicate and slaughtered. Blood and serum was collected for haematological analysis, serum } \\
\text { bioassay and HA/HI tests to determine antibody titres against ND vaccines. All data collected were } \\
\text { subjected to one-way analysis of variance using SPSS software package. Results showed that } \\
\text { haematological parameters were significantly influenced by the dietary treatments in which birds } \\
\text { fed } 50 \% \text { equi-protein replacement of SBM with GNC had better PCV, basophil, MCH and MCHC } \\
\text { values compared to that of birds in the other dietary treatments. The antibody titres of experimental } \\
\text { birds were not significantly different among treatment groups. The diet with } 50 \% \text { equi-protein } \\
\text { replacement of SBM with GNC elicited the highest antibody titres of Log } 8 \text { and Log } 210 \text { after the } \\
1^{\text {st }} \text { and } 2^{\text {nd }} \text { ND vaccinations when compared to the other diets. The serum total protein, globulin, } \\
\text { albumin, and glucose were significantly influenced by the dietary treatments. The present result } \\
\text { indicate that } 50 \% \text { equi-protein replacement of SBM with GNC in diets is not detrimental to health } \\
\text { status of broiler chickens. }\end{array}$ \\
\hline
\end{tabular}

\section{Introduction}

Feeding has been recognized as an important aspect of livestock production as it accounts for $60-70 \%$ of the cost of poultry production under intensive system (Adesua et al., 2010). High cost of feeds is one of the major problems facing poultry production in Nigeria (Akintunde and Adeoti, 2014) which has necessitated the feed manufacturers to frequently vary their formula and the ingredients being used. This variation is usually based on the price difference among the feed ingredients that can replace one another.

The major protein concentrates used in animal feed formulation are the oil seed meals such as the soybean meal (SBM) and groundnut cake (GNC) which usually have their crude protein content above 40\% (Adeniji, 2008). Though, poultry especially chickens have the potential to bridge the gap between supply and demand of animal protein as purported by Bashar (2010), the main problem in developing countries like Nigeria is due to the fact that livestock farmers have been depending on the importation of soybean and some other proteinaceous feed ingredients. This has therefore led to increasing high cost of poultry feed production and depletion of Nigerian foreign reserve.

Soybean meal is an excellent source of plant protein, except for its deficiency in methionine and the fact that it contains trypsin inhibitors which cause enlargement of pancreas in chicks. Hence it is usually subjected to heat treatment prior to use as animal feed in order to destroy the anti-nutritional factors (Rocha et al., 2014). However, the use of Soybean meal in Nigeria had been limited due to low production of soybean seed and the consequent high cost. 
Groundnut (Arachis hypogea) on the other hand is widely cultivated in Nigeria and is a valuable source of vitamins $\mathrm{E}, \mathrm{K}$ and $\mathrm{B}$. It is the richest plant source of thiamine (B1) and also rich in niacin, which is low in cereals (FAO, 2000). Groundnut has agreeable flavour when roasted and its high protein content makes it especially valuable as a tissue builder (Atasie et al., 2009). Hence groundnut cake is readily available and has a comparable crude protein content with soybean meal, though deficient in lysine and methionine.

Therefore, this study was designed to examine the effect of equi-protein replacement of Soybean meal with Groundnut cake on humoral immune response to Newcastle disease (ND) vaccinations, blood and serum indices of broiler chickens.

\section{Materials and Method}

\section{Experimental Site}

The feeding trial was conducted at the Poultry Unit of the Teaching and Research Farm, Federal University of Technology Akure, while laboratory analysis was carried out at the Microbiology and Nutritional Laboratory of the Department of Animal Production and Health, Federal University of Technology Akure, Ondo state, Nigeria.

\section{Experimental Diets}

Soybean meal (SBM) and Groundnut cake (GNC) with other feed ingredients were purchased from a reputable feed mill in Akure. Five (5) equi-protein experimental diets with varying levels of soybean meal (SBM) and groundnut cake (GNC) were formulated (Table 1). The first diet was a control diet with $100 \% \mathrm{SBM}$ as the major plant protein source and designated as Diet I while in other diets, SBM was replaced with $25 \%$ GNC (Diet II), 50\% GNC (Diet III), 75\% GNC (Diet IV) and 100\% GNC (Diet V).

\section{Experimental Animals and Layout}

A total of One hundred and twenty (120) Cobb's day old chicks were procured from a reputable hatchery. The chicks were housed on deep litter and conventional brooding method and poultry management was practiced. The birds were randomly selected and distributed into the five (5) dietary treatments of three (3) replicates and eight (8) chicks per replicate using a completely randomized design. Their respective diets were fed ad-libitum throughout the experimental period which lasted for 56 days. The birds were administered Newcastle disease (ND) vaccines following a stipulated vaccination regime- ND Hitchner B1 strain intra-occular at 3 days old and ND LaSota strain at 28 days old.

\section{Sample Collection and Laboratory Analysis}

Blood and serum samples were collected from birds in each treatment group at day old via the heart to determine baseline maternal antibody against Newcastle disease (ND) virus. Thereafter bleeding was done 10 days after each vaccination process for haematological and serological analysis where the birds were bled through the jugular vein.

\section{Laboratory Analysis}

\section{Haematological Analysis}

Using method described by Lamb (1981) blood samples were analysed for Packed cell volume (PCV), red blood cell count (RBC), haemoglobin concentration (HB), erythrocyte sedimentation rate (ESR) and white blood cell differentials. The Mean Corpuscular Haemoglobin Concentration (MCHC), Mean Corpuscular Haemoglobin $(\mathrm{MCH})$ and the Mean Corpuscular Volume (MCV) were also calculated accordingly.

Table 1. Gross composition of experimental diets fed Broiler chickens

\begin{tabular}{|c|c|c|c|c|c|}
\hline \multirow{3}{*}{ Ingredients } & Diet 1 & Diet II & Diet III & Diet IV & Diet V \\
\hline & \multicolumn{5}{|c|}{ \% Equip-protein replacement of SBM with GNC } \\
\hline & 0 & 25 & 50 & 75 & 100 \\
\hline Maize & 50.00 & 50.00 & 50.00 & 50.00 & 50.00 \\
\hline Wheat offal & 10.00 & 10.00 & 10.00 & 10.00 & 10.00 \\
\hline Brewers dried grain & 6.00 & 6.13 & 6.26 & 6.28 & 6.41 \\
\hline Soybean meal (42\% CP) & 28.00 & 21.00 & 14.00 & 7.00 & 0.00 \\
\hline Groundnut cake (44\% CP) & 0.00 & 6.68 & 13.36 & 20.05 & 26.73 \\
\hline Bone meal & 3.00 & 3.00 & 3.00 & 3.00 & 3.00 \\
\hline Oyster shell & 0.35 & 0.35 & 0.35 & 0.35 & 0.35 \\
\hline Lysine & 0.20 & 0.29 & 0.38 & 0.47 & 0.56 \\
\hline Methionine & 0.30 & 0.30 & 0.30 & 0.30 & 0.30 \\
\hline Vitamins/Minerals Premix & 0.25 & 0.25 & 0.25 & 0.25 & 0.25 \\
\hline Salt & 0.30 & 0.30 & 0.30 & 0.30 & 0.30 \\
\hline Palm oil & 1.60 & 1.70 & 1.80 & 2.00 & 2.10 \\
\hline Total & 100.00 & 100.00 & 100.00 & 100.00 & 100.00 \\
\hline \multicolumn{6}{|c|}{ Calculated analysis } \\
\hline Crude protein $(\%)$ & 19.53 & 19.64 & 19.75 & 19.85 & 19.96 \\
\hline $\mathrm{ME}(\mathrm{kcal} / \mathrm{kg})$ & 2908.04 & 2906.11 & 2904.17 & 2908.46 & 2906.53 \\
\hline Crude fibre $(\%)$ & 5.22 & 5.13 & 5.03 & 4.91 & 4.82 \\
\hline Ether extract (\%) & 5.24 & 5.50 & 5.76 & 6.11 & 6.38 \\
\hline Calcium (\%) & 1.32 & 1.32 & 1.32 & 1.32 & 1.32 \\
\hline Phosphorus (\%) & 0.62 & 0.61 & 0.60 & 0.60 & 0.59 \\
\hline Lysine (\%) & 1.25 & 1.25 & 1.25 & 1.25 & 1.25 \\
\hline Methionine (\%) & 0.60 & 0.59 & 0.58 & 0.57 & 0.56 \\
\hline
\end{tabular}


Haemagglutination and Haemagglutination Inhibition Test (HA/HI Test)

Serum samples taken from the experimental broiler chickens were analysed using beta ( $\beta$ ) micro haemagglutination inhibition technique as described by Thayer and Beard, (1998). This was to determine the antibody titre levels as a measure of the humoral immune response elicited in the experimental birds to Newcastle disease vaccinations.

\section{Serum Biochemical Analysis}

Diagnostic kits (Randox Laboratories, UK Test Kits) was used to analyse these serum biochemical parametersTotal protein, Globulin, Albumin, Glucose, Cholesterol, Urea, Creatinine, Trigylceride, High Density Lipoprotein, Low Density Lipoprotein Alanine transferase, Alanine phosphatase and Aspartate transaminase of the experimental broiler chickens.

\section{Statistical Analysis}

Data collected were subjected to one-way Analysis of variance (ANOVA) using SPSS version 17 package and where significant differences $(\mathrm{P}<0.05)$ exists, Duncan's Multiple Range Test (DMRT) of the same package was used to compare the means.

\section{Results}

\section{Haematological Parameters of Experimental Broiler Chickens}

Haematological parameters of broiler chickens fed graded levels of GNC in replacement for SBM are presented in Table 2. The lymphocyte, monocyte, heterophils and eosinophils were not significantly $(\mathrm{P}>0.05)$ influenced by the dietary treatments among all parameters measured. The PCV value of birds fed Diet V $(26.17 \pm 1.56 \%)$ was significantly $(\mathrm{P}<0.05)$ lower than that of birds fed Diet I (29.67 $\pm 0.67 \%)$, Diet III (29.00 $\pm 0.97 \%)$ and Diet IV $(28.83 \pm 1.28 \%)$ but was not significantly different $(\mathrm{P}>0.05)$ from that of birds fed Diet II $(28.67 \pm 1.09 \%)$. The HBC value recorded for birds fed Diet
$\mathrm{V}(8.70 \pm 0.53 \mathrm{~g} / 100 \mathrm{ml})$ was significantly $(\mathrm{P}<0.05)$ different from that of birds fed other test diets. The RBC count of birds fed Diet I $(2.75 \pm 0.18 \times 106 / \mathrm{mm} 3)$ was significantly $(\mathrm{P}<0.05)$ higher than the RBC count $(1.98 \pm 0.36 \times 106 / \mathrm{mm} 3)$ of birds fed Diet V. The MCV and $\mathrm{MCH}$ values recorded for birds fed Diet V $(143.38 \pm 0.13$ $\mu 3 ; 47.63 \pm 0.43 \mathrm{pg})$ was significantly $(\mathrm{P}<0.05)$ higher compared to that of birds fed Diet I $(109.52 \pm 0.05 \mu 3$; $36.50 \pm 0.17 \mathrm{pg})$. The $\mathrm{MCHC}$ value for birds fed Diet II $(33.28 \pm 0.05 \mathrm{~g} / \mathrm{dl})$ was significantly higher $(\mathrm{P}<0.05)$ than that of birds fed Diets IV $(33.23 \pm 0.05 \mathrm{~g} / \mathrm{dl})$ and V $(33.24 \pm 0.06 \mathrm{~g} / \mathrm{dl})$. The ESR of birds fed Diet V $(33.83 \pm 0.54 \mathrm{~mm} / \mathrm{hr})$ differed significantly $(\mathrm{P}<0.05)$ from that of birds fed Diet I $(2.83 \pm 0.17 \mathrm{~mm} / \mathrm{hr})$. The basophil counts for birds fed Diets II $(3.33 \pm 0.21 \%)$ and III $(3.17 \pm 0.17 \%)$ was significantly higher from that of birds fed diet III $(2.17 \pm 0.17 \%)$.

\section{Antibody Titres of Experimental Birds in Response to Newcastle Disease Vaccinations}

The antibody titre values in response to ND vaccinations of the experimental chickens are presented in Table 3. The experimental birds recorded a baseline maternal antibody titre of $\log _{2} 5$ across the dietary treatment groups at day old. The varying diets did not have significant $(\mathrm{P}>0.05)$ effect on the antibody titre levels after the ND vaccinations among the different treatments. The birds fed 50\% equi-protein replacement of SBM with GNC (Diet III) recorded the highest antibody titres of $\log _{2} 8$ and $\log _{2} 10$ after the $1^{\text {st }}$ and $2^{\text {nd }} \mathrm{ND}$ vaccinations respectively. While birds fed Diet V with 100\% GNC had the lowest titre values of $\log _{2} 6$ and $\log _{2} 8$ after the ND vaccinations.

\section{Serum Biochemical Parameters}

Table 4 shows the serum biochemical indices of broilers chicken fed diets containing soybean meal replaced with groundnut cake. Among the serum biochemical parameters, the total protein, albumin, globulin and glucose differed significantly $(\mathrm{P}<0.05)$ among the treatment groups as influenced by the varying diets.

Table 2. Haematological parameters of broiler chickens fed diets containing soybean meal replaced with groundnut cake

\begin{tabular}{|c|c|c|c|c|c|}
\hline \multirow{4}{*}{ Parameters } & \multicolumn{5}{|c|}{ Treatments } \\
\hline & I & II & III & IV & $\mathrm{V}$ \\
\hline & \multicolumn{5}{|c|}{ \% equi-protein replacement of SBM with GNC } \\
\hline & 0 & 25 & 50 & 75 & 100 \\
\hline $\mathrm{PCV}(\%)$ & $29.67 \pm 0.67^{\mathrm{a}}$ & $28.67 \pm 1.09^{\mathrm{ab}}$ & $29.00 \pm 0.97^{\mathrm{a}}$ & $28.83 \pm 1.28^{\mathrm{a}}$ & $26.17 \pm 1.56^{\mathrm{b}}$ \\
\hline $\mathrm{HBC}(\mathrm{g} / \mathrm{dl})$ & $9.88 \pm 0.21^{\mathrm{a}}$ & $9.57 \pm 0.37^{\mathrm{a}}$ & $9.65 \pm 0.32^{\mathrm{a}}$ & $9.58 \pm 0.43^{\mathrm{a}}$ & $8.70 \pm 0.53^{\mathrm{b}}$ \\
\hline $\operatorname{RBC}\left(10^{6} / \mathrm{mm}^{3}\right)$ & $2.75 \pm 0.18^{\mathrm{a}}$ & $2.45 \pm 0.26^{\mathrm{ab}}$ & $2.56 \pm 0.26^{\mathrm{ab}}$ & $2.60 \pm 0.29^{\mathrm{ab}}$ & $1.98 \pm 0.36^{\mathrm{b}}$ \\
\hline $\operatorname{MCV}\left(\mu^{3}\right)$ & $109.52 \pm 0.05^{\mathrm{b}}$ & $121.18 \pm 0.09^{\mathrm{ab}}$ & $117.69 \pm 0.10^{\mathrm{ab}}$ & $117.13 \pm 0.12^{\mathrm{ab}}$ & $143.38 \pm 0.13^{\mathrm{a}}$ \\
\hline $\mathrm{MCH}(\mathrm{pg})$ & $36.50 \pm 0.17^{\mathrm{b}}$ & $40.43 \pm 0.28^{\mathrm{ab}}$ & $39.16 \pm 0.32^{\mathrm{ab}}$ & $38.91 \pm 0.38^{\mathrm{ab}}$ & $47.63 \pm 0.43^{\mathrm{a}}$ \\
\hline $\mathrm{MCHC}(\mathrm{g} / \mathrm{dl})$ & $33.32 \pm 0.04^{\mathrm{ab}}$ & $33.37 \pm 0.04^{\mathrm{a}}$ & $33.28 \pm 0.05^{\mathrm{ab}}$ & $33.23 \pm 0.05^{\mathrm{b}}$ & $33.24 \pm 0.06^{\mathrm{b}}$ \\
\hline $\operatorname{ESR}(\mathrm{mm} / \mathrm{hr})$ & $2.83 \pm 0.17^{\mathrm{c}}$ & $3.00 \pm 0.26^{\mathrm{bc}}$ & $3.00 \pm 0.26^{\mathrm{bc}}$ & $3.33 \pm 0.33^{b}$ & $3.83 \pm 0.54^{\mathrm{a}}$ \\
\hline Lymphocyte (\%) & $59.33 \pm 0.42$ & $60.17 \pm 0.54$ & $59.67 \pm 0.80$ & $59.50 \pm 0.76$ & $61.33 \pm 0.96$ \\
\hline Monocyte (\%) & $11.67 \pm 1.38$ & $13.00 \pm 1.24$ & $11.83 \pm 0.95$ & $12.83 \pm 1.14$ & $13.17 \pm 1.40$ \\
\hline Heterophils (\%) & $25.17 \pm 1.49$ & $22.83 \pm 1.17$ & $24.83 \pm 1.35$ & $23.67 \pm 1.33$ & $23.83 \pm 1.70$ \\
\hline Eosnophils (\%) & $1.17 \pm 0.31$ & $0.87 \pm 0.33$ & $1.50 \pm 0.22$ & $0.83 \pm 0.31$ & $0.67 \pm 0.21$ \\
\hline Basophils (\%) & $2.67 \pm 0.21^{\mathrm{ab}}$ & $3.33 \pm 0.21^{\mathrm{a}}$ & $2.17 \pm 0.17^{\mathrm{b}}$ & $3.17 \pm 0.17^{\mathrm{a}}$ & $2.67 \pm 0.33^{\mathrm{ab}}$ \\
\hline
\end{tabular}

Mean \pm standard error of mean, a,b,c $=$ Means within the same row with different superscripts are significantly $(\mathrm{P}<0.05)$ different. $\mathrm{n}=3 \mathrm{PCV}: \mathrm{Packed}$ Cell Volume, Hbc: Haemoglobin concentration, RBC: Red Blood Cell, MCHC: Mean Cell Haemoglobin Concentration, MCV: Mean Cell Volume, MCH: Mean Cell Haemoglobin. ESR: Erythrocyte sedimentation rate 
Table 3. Antibody titres of broiler chickens fed diets containing soybean meal replaced with groundnut cake after Newcastle disease vaccinations

\begin{tabular}{|c|c|c|c|c|c|}
\hline & \multicolumn{5}{|c|}{ Treatments } \\
\hline & I & II & III & IV & $\mathrm{V}$ \\
\hline & \multicolumn{5}{|c|}{$\%$ equi-protein replacement of SBM with GNC } \\
\hline Antibody titres & 0 & 25 & 50 & 75 & 100 \\
\hline Baseline titres & $\log _{2} 5$ & $\log _{2} 5$ & $\log _{2} 5$ & $\log _{2} 5$ & $\log _{2} 5$ \\
\hline Titres after $1^{\text {st }}$ ND vaccine & $\log _{2} 7$ & $\log _{2} 7$ & $\log _{2} 8$ & $\log _{2} 7$ & $\log _{2} 6$ \\
\hline Titres after $2^{\text {nd }}$ ND vaccine & $\log _{2} 9$ & $\log _{2} 9$ & $\log _{2} 10$ & $\log _{2} 9$ & $\log _{2} 8$ \\
\hline
\end{tabular}

ND- Newcastle disease

Table 4. Serum biochemical indices of broiler chickens fed diets containing soybean meal replaced with groundnut cake

\begin{tabular}{|c|c|c|c|c|c|}
\hline \multirow{4}{*}{ Parameters } & \multicolumn{5}{|c|}{ Treatments } \\
\hline & I & II & III & IV & $\mathrm{V}$ \\
\hline & \multicolumn{5}{|c|}{$\%$ equi-protein replacement of SBM with GNC } \\
\hline & 0 & 25 & 50 & 75 & 100 \\
\hline Total protein $(\mathrm{g} / \mathrm{dl})$ & $34.03 \pm 0.48^{\mathrm{a}}$ & $34.49 \pm 1.00^{\mathrm{a}}$ & $34.65 \pm 1.03^{\mathrm{a}}$ & $33.53 \pm 1.43^{\mathrm{a}}$ & $31.80 \pm 0.41^{b}$ \\
\hline Globulin(g/dl) & $28.70 \pm 0.23^{b}$ & $28.80 \pm 0.11^{b}$ & $29.43 \pm 0.14^{\mathrm{a}}$ & $28.66 \pm 0.24^{b}$ & $28.43 \pm 0.27^{\mathrm{b}}$ \\
\hline $\operatorname{Albumin}(\mathrm{g} / \mathrm{dl})$ & $5.33 \pm 0.59^{\mathrm{a}}$ & $5.79 \pm 1.23^{\mathrm{a}}$ & $5.99 \pm 1.26^{\mathrm{a}}$ & $5.10 \pm 1.43^{\mathrm{a}}$ & $2.37 \pm 0.50^{\mathrm{b}}$ \\
\hline Glucose (g/dl) & $117.94 \pm 19.91^{\mathrm{c}}$ & $169.47 \pm 14.55^{\mathrm{b}}$ & $228.32 \pm 36.7^{\mathrm{a}}$ & $228.32 \pm 23.58^{\mathrm{a}}$ & $145.32 \pm 19.25^{\mathrm{b}}$ \\
\hline Cholesterol(mg/l) & $286.3 \pm 29.67$ & $291.11 \pm 44.13$ & $297.25 \pm 22.51$ & $289.72 \pm 35.18$ & $286.64 \pm 30.12$ \\
\hline Creatinine $(\mathrm{mg} / \mathrm{dl})$ & $7.39 \pm 0.70$ & $7.52 \pm 1.02$ & $7.75 \pm 0.46$ & $7.38 \pm 0.69$ & $7.00 \pm 0.81$ \\
\hline $\operatorname{Urea}(\mathrm{mmol} / \mathrm{l}) .2$ & $43.53 \pm 3.48$ & $44.48 \pm 5.17$ & $45 \pm 2.53$ & $43.56 \pm 3.52$ & $41.58 \pm 4.13$ \\
\hline $\mathrm{HDL}(\mathrm{mmol} / \mathrm{l})$ & $17.01 \pm 1.68$ & $16.18 \pm 1.34$ & $14.29 \pm 1.48$ & $14.21 \pm 1.43$ & $14.36 \pm 2.02$ \\
\hline TRG(mmol/l) & $243.68 \pm 15.87$ & $244.48 \pm 23.8$ & $251.31 \pm 11.06$ & $234.8 \pm 18.82$ & $243.85 \pm 16.12$ \\
\hline $\mathrm{LDL}(\mathrm{mmol} / \mathrm{l})$ & $220.56 \pm 27.92$ & $226.04 \pm 40.34$ & $232.7 \pm 21.08$ & $208.54 \pm 30.66$ & $223.5 \pm 28.05$ \\
\hline ALT(UI/l) & $7.67 \pm 7.71$ & $7.02 \pm 2.22$ & $7.20 \pm 3.23$ & $7.31 \pm 3.51$ & $6.82 \pm 1.25$ \\
\hline AST(UI/l) & $15.86 \pm 7.69$ & $14.06 \pm 5.2$ & $13.41 \pm 3.69$ & $13.55 \pm 6.84$ & $12.06 \pm 8.01$ \\
\hline ALP(UI/l) & $620.08 \pm 82.27$ & $628.82 \pm 122.79$ & $653.2 \pm 60.8$ & $621.00 \pm 83.54$ & $574.08 \pm 97.55$ \\
\hline
\end{tabular}

Mean \pm standard error of mean, a,b,c=Means within the same row with different superscripts are significantly (P<0.05) different, TRG: Trigylceride, HDL: High Density Lipoprotein, LDL: Low Density Lipoprotein, AST: Aspartate Aminotransferase, ALT: Alanine Aminotransfererase , ALP: Alkaline Phosphatase

The serum total protein of birds fed Diets I $(34.03 \pm 0.4 \mathrm{~g} / \mathrm{dl})$, II $(34.49 \pm 1.00 \mathrm{~g} / \mathrm{dl})$, III $(34.49 \pm 1.00 \mathrm{~g} / \mathrm{dl})$ and IV $(33.53 \pm 1.43 \mathrm{~g} / \mathrm{dl})$ were not significantly different $(\mathrm{P}>0.05)$ from each other, but differed significantly $(\mathrm{P}<0.05)$ from that of birds fed Diet V $(31.80 \pm 0.41 \mathrm{~g} / \mathrm{dl})$. The globulin value of birds fed diet III $(29.43 \pm 0.14 \mathrm{~g} / \mathrm{dl})$ was significantly higher $(\mathrm{P}<0.05)$ than that of birds fed other diets. The albumin value of birds fed Diet $\mathrm{V}$ $(2.37 \pm 0.50 \mathrm{~g} / \mathrm{dl})$ was significantly $(\mathrm{P}<0.05)$ different from that of birds fed the rest test diets. The serum glucose concentration of birds fed diets III $(228.32 \pm 36.7 \mathrm{~g} / \mathrm{dl})$, IV $(228.32 \pm 23.58 \mathrm{~g} / \mathrm{dl})$ were not significantly different $(\mathrm{P}>0.05)$ from each but differed significantly $(\mathrm{P}<0.05)$ from that of birds in the other treatment groups.

\section{Discussion}

Haematological parameters have been associated with health indices and are of diagnostic significance in routine clinical evaluation of the state of health (Saliu et al., 2012). The PCV values of experimental birds in this study varied between $26.17-29.67 \%$ which falls within the normal range of $25-45 \%$ for chickens as reported by Akinmutimi (2004) and Ahamefule et al. (2006). PCV values below normal range is an indication of anaemia (Radostits et al., 1994) and poor quality of protein in the diet (Awoniyi et al., 2000). Dietary effect on the PCV of experimental birds showed that birds fed $50 \%$ equi-protein replacement of SBM with GNC diet had better PCV value compared to the other dietary treatments aside from birds fed the control diet that recorded the highest PCV value.

Replacement of SBM up to 50\% with GNC also tended towards an improvement of RBC and MCV values. This implied that oxygen carrying capacity of the birds has not been compromised by these replacement level. While, reduction in the values of haemoglobin and red blood cell (RBC) observed in birds fed 100\% replacement of SBM with GNC could be signs of anaemia as reported by Mohammed and Oloyede (2009). The study revealed that replacement of SBM with GNC in diet of broiler chickens led to an increase in the basophil, $\mathrm{MCH}$ and $\mathrm{MCHC}$ values compared to control. However, this higher values were still within the normal range as reported by Ross et al, (1978). This suggests that the birds were able to tolerate the experimental diets health-wise as even report by Isaac et al. (2013) states that animals with good blood composition are likely to be healthy and have good performance.

The nutrients which have an immuno-modulating effect include protein and energy (Praharaj et al., 1999). The variable protein source offered to the birds in this study had no significant effect on the immune response of experimental birds to ND vaccinations. This result is similar to that reported by Golian et al. (2010) that did not find any significant change in antibody titers due to the feeding of varying levels of protein and energy diets. This was further corroborated by Haunshi et al. (2012) which stated there was no significant effect on antibody titre against NCD vaccine in Aseel breed of chickens fed diets with varying protein concentrations. Also, this study is in line with the work of Perween et al. (2015) that the better immune response recorded in the birds fed $50 \%$ equi-protein replacement of SBM with GNC might be due to better nutrient utilization and its extension toward the better humoral immunological response. Furthermore, the result of this present study is buttressed by Jahanian (2010a) which stated conclusively that dietary $\mathrm{CP}$ and individual amino acids have important 
roles in immune function since the different diets elicited varying levels of antibody titres.

Serum proteins have been implicated as a pointer to strong amino acid metabolism (Shulkla and Pachaurii, 1995). Birds fed $100 \%$ replacement of SBM with GNC diet recorded the lowest total protein, globulin and albumin values, suggesting inferiority of the diet in protein balance in comparison with the other experimental diets. This results agreed with observations of Bolu and Balogun (2009) that decreased serum protein concentration is an indication of alteration of normal protein metabolism due to interference of protein utilization. Differences observed in glucose level shows that birds fed $50 \%$ equi-protein replacement of SBM with GNC and $75 \%$ replacement of SBM with GNC diet had highest glucose levels, thus implying that birds fed these diets had increased energy levels which may lead to improvement of their productive performance. Also the diet with $100 \%$ replacement of SBM with GNC led to a decrease in the ALT, AST and ALP values compared to the control group. This suggests that the efficiency of liver functioning in birds fed diet with $100 \%$ GNC as protein source may be slightly reduced when compared to birds in the other groups since these enzymes are produced in the liver.

\section{Conclusion}

Result obtained from this study showed that replacement of soybean meal (SBM) with groundnut cake (GNC) at $50 \%$ equi-protein replacement of SBM with GNC optimally enhanced humoral immune status of birds fed this diet as reflected in the high antibody titres elicited in response to ND vaccinations and better haematological and serum biochemical indices. Hence, $50 \%$ equi-protein replacement of SBM with GNC in broiler chicken diets is suggested for poultry farmers especially those engaged in meat type production for better productive performance without compromising the health status of the chickens.

\section{References}

Adeniji AA. 2008. Replacement Value of Soyabean Meal with Groundnut Cake with or Without Fishmeal Supplementation in Diets of Pullet Chicks. Journal of Applied Sciences Research, 4(10): 1249-1252.

Adesua A, Onibi GE. 2014. Growth performance, haematology and meat quality of broiler chickens fed rumen liquorfermented wheat bran-based diets. Journal of Agriultural Science. 10(4): 725-736.

Ahamefule FO, Eduok GO, Usman A, Amaefule KU, Obua BE, Oguike SA. 2006. Blood biochemistry and haematology of weaner rabbits fed sundried, ensiled and fermented cassava peel based diets. Pakistan Journal of Nutrition. 5 (3): 248-253.

Akinmutimi AH. 2004. Evaluation of sword beans (Canavalia gladiata) as an alternative feed resource for broiler chickens. $\mathrm{PhD}$ thesis. Michael Okpara University of Agriculture Umudike, Nigeria.

Akintunde OK, Adeoti AI. 2014. Assessment of Factors Affecting the Level of Poultry Disease Management in Southwest, Nigeria. Trends in Agricultural Economics, 7 (2): 41-56, 2014

Alhassan K, Agbenorhevi JK, Asibuo JY, Sampson GO. 2017. Proximate Composition and Functional Properties of Some New Groundnut Accessions. Journal of Food Security, 5(1): 9-12

Atasie VN, Akinhanmi TF, Ojiodu CC. 2009. Proximate Analysis and Physico-Chemical Properties of Groundnut (Arachis hypogaea L.). Pakistan Journal of Nutrition, 8 (2): 194-197.
Awoniyi TAM, Aletor VA, Aina JM. 2003. Performance of broiler-chickens fed on maggot meal in place of fish meal. International Journal of poultry Science, 2(4): 271-274.

Bashar YA, Tukur HM, Sekoni AA, Hassan WA. 2010. Nutrient Retention and Haematological Indices of Broiler Starters Fed Lablab Seed Meal as the source of Protein. Nigeria Journal of Basic Applied Science, 18(2): 285-291.

Bolu SA, Balogun OO. 2009. Effects of improved (addition of antimicrobials and antioxidants) locally produced natural vitamin premix on performance, haematology and some serum constituents of broiler chickens. Nigerian Journal of Animal Production. 36 (2): 246-255.

FAO, 2000. Food and Agricultural Organization. Groundnut (Arachis hypogaea). Encyclopedia of Agricultural Sciences Volume 3.

Golian A, Azghadi M, Pilevar M. 2010. Influence of various levels of energy and protein on performance and humoral immune responses in broiler chicks. Global Veterinaria 4 (5): 434-440.

Haunshi S, Panda AK, Rajkumar U, Padhi MK, Niranjan M, Chatterjee RN. 2012. Effect of feeding different levels of energy and protein on performance of Aseel breed of chicken during juvenile phase. Tropical Animal Health Production. 44(7): 1653-1658.

Isaac LJ, Abah G, Akpan B, Ekaette IU. 2013. Haematological properties of different breeds and sexes of rabbits. Proceedings of the $18^{\text {th }}$ Annual Conference of Animal Science Association of Nigeria. Pp.22-24.

Jahanian R. 2010a. Effects of dietary threonine on performance and immunocompetence of starting broiler chicks. 2nd International Veterinary Poultry Congress; Feb 20-21; Tehran. Iran. p.200.

Lamb GB. 1981. Manual of Veterinary Techniques in Kenya. Published by CIBA-GEIGY, 127-147.

Muhammad NO, Oloyede OB. 2009. Protein fractions and amino acid profile of Aspergillus niger-fermented Terminalia catappa seed meal. African Journal of Microbiology Research, 3(3): 101 - 104.

Perween, S, Kumar K, Chandramoni Kumar S, Singh PK, Kumar A, Paswan JK, Kumar M. 2015. Effect of feeding different dietary level of energy and protein on immune response of Vanaraja chicken. Proceedings of IX Biennial Conference of Animal Nutrition Association held on 22-24, January 2015 in Guwahati, India. NAH-02.

Praharaj NK, Reddy MR, Rao SVR, Shyamsunder G, Reddy BLN. 1999. Energy by sire family interactions for growth, feed efficiency, immune competence in commercial broilers. Arch. Geflugelkd. 63: 82-86.

Radostits OM, Blood OC, Gay CC. 1994. Veterinary Medicine, $8^{\text {th }}$ Edition, Bailliere Tindall, pp.121-1224

Ross J, Chistie G, Halliday W, Gade Jone RM. 1978. Haematological and blood comparison value for clinical pathology in poultry. Veterinary Record, 102: 29-31.

Rocha C, Durau JF, Barrilli LNE, Dahlke F, Maiorka P, Maiorka A. 2014. The effect of raw and roasted soybeans on intestinal health, diet digestibility and pancreas weight of broilers. Journal of Applied Poultry Research, 23(1): 71-79

Saliu JA, Elekofehinti OO, Komolafe K, Oboh G. 2012. Effects of some green leafy vegetables on the haematological parameters of diabetic rats. Scholars Research Library. Journal of Natural Product and Plant Resources, 2(4): 7-15.

Shukla SK, Pachaurii SP. 1995. Blood biochemical profiles in induced aflatoxicosis of cockerels. British Poultry Science.36: 1545-1560

Thayer SG, Beard CW. 1998. Serological Procedure In: A Laboratory Manual for the Isolation and Identification of Avian Pathogens, 4th Ed. Amer. Assoc. Avian Pathologist, Pennsylvania, USA, pp: 255-258. 